\title{
Spectators and Spectacle in Quintus' Posthomerica
}

\author{
Irene J.F. de Jong \\ University of Amsterdam, Dept. of Classics \\ Amsterdam, The Netherlands \\ i.j.f.dejong@uva.nl
}

Received February 2021 | Accepted April 2021

\begin{abstract}
Quintus' literary reputation is on the rise, in the wake of a general reappreciation of late antique literature. In my article I discuss Quintus' use of embedded focalization: when we look at events through the eyes of one of the characters. Quintus uses this narrative device both in the same way as Homer, but also in original new ways. One such new way is the serial use of embedded focalization at the moment of arrival of a champion. The ample use of embedded focalization can be added to the list of stylistic features which contribute to the well-known visual aesthetics of late antique poetry, such as ekphrasis, miniaturization, enumeration, and the juxtaposition of episodic scenes. But I also argue that Quintus through the ubiquitous presence of spectators frames the action of his story as a spectacle, a race or gladiatorial show, which gods and characters and hence his narratees, watch as if sitting in an amphitheatre or circus.
\end{abstract}

\section{Keywords}

Quintus of Smyrna - Homer - embedded focalization - narratology - late antique poetry - characterization - similes - divine audience - theatricality - gladiator

Quintus' literary reputation is on the rise. In the wake of a general reappreciation of late antique literature, a series of recent studies have shown how his apparently close imitatio of Homeric language actually leaves room for considerable aemulatio. ${ }^{1}$ When we broaden the scope of our analysis from language

1 See esp. Baumbach and Bär 2007; Bär 2009; Maciver 2012; Scheijnen 2018. 
to narrative style there is, I suggest, even more originality to be detected. Thus, to give one example right away, Quintus' depiction of the Trojans' drunkenness during the first night after the 'departure' of the Greeks has, so far as we can judge on the basis of the texts available to us, no epic precedent: ${ }^{2}$

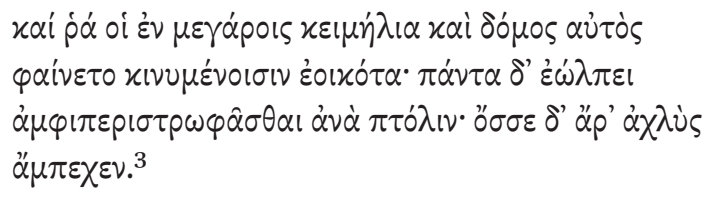

The household furniture and the very house seemed to be moving, and they had the impression that the whole of the city was spinning round and round as their eyes grew dim.

This example is not randomly chosen but allows me to introduce the topic of this study. In what follows I will discuss Quintus' use of embedded focalization: when he does not present events through his own eyes (the default narrative situation in the Posthomerica, as in all ancient epics) but through those of one of his characters. In the example just given we enter the mind of the Trojans and look with their (drunken) eyes at the world around them.

I will argue that Quintus frequently employs this narrative device, in the same way but also in different ways than those we know from the Homeric epics. ${ }^{4}$ Lovatt's seminal study on the epic gaze will allow me, from time to time, also to take into account the epic tradition between Homer and Quintus. ${ }^{5} \mathrm{My}$ study, thus, is an example of intertextual narratology. ${ }^{6}$ In the final part I will contextualize Quintus' ample inclusion of spectators, connecting it to the theatricalization which characterizes the Graeco-Roman world from the second century $\mathrm{AD}$ onwards, the penchant for visuality of late antique literature, and

2 The only parallel I can think of is Euripides' depiction of Pentheus' Dionysiac double vision in $B a .918-921$.

3 Q.S. 13.9-12. I quote the text and translation of Hopkinson 2018 (with occasional adaptations, which are often inspired by James' translation of 2004).

4 Together with E.M. van Opstall I supervised in 2017 an MA-thesis on 'Embedded focalization and visuality in Quintus Smyrnaeus' Posthomerica' by I. Argyrouli.

5 Lovatt 2013. When making such comparisons with Latin epic texts, it must remain open whether Quintus knew these, i.e. whether we are dealing with intertextuality on his part or merely with our own scholarly 'gaze' which can have this broad overview (although of course we, in turn, may be lacking Greek texts that were still available to Quintus). For a recent update on the debate, see James 2007 .

6 See de Jong 2019 and the entire issue of Symbolae Osloenses devoted to narratology and intertextuality. 
the arena spectacles of his time (which scholars now generally take to be the third century AD).

In order to lay the foundation for my discussion of Quintus, I will start with a brief look at Homer's use of embedded focalization in the Iliad. In what contexts do we find this device and what are its functions? ${ }^{7}$

\section{$1 \quad$ Embedded Focalization in the Iliad $^{8}$}

A frequent use of embedded focalization concerns the divine audience. Time and again (18 instances) the Homeric narrator records that the battles between Greeks and Trojans are watched by a god or the gods collectively, who may be merely enjoying the spectacle as a form of entertainment while they sit in their Olympian 'sky-boxes' but who often are emotionally moved by what they see and interfere in the action. One example is Poseidon, who watches Priam's city and the ships of the Greeks from a peak of Samothrace and on seeing that the Greeks are being beaten by the Trojans, comes down and starts encouraging them (Il. 13.10-16). ${ }^{9}$ Even when they do not intervene in events on earth, the constant interest in human affairs by the gods has an important function: "The divine audience both exalts and humbles human action. It is exalted by being made the object of passionate concern by the gods, and at the same time it is shown as trivial in the sublime perspective of heaven". ${ }^{10}$

Mortal spectators, too, usually old men or women, watch the battle on the plain before Troy from the walls in a teichoscopy, for instance Priam and the old men of Troy, joined by Helen (3.161-244). Their watching does not lead to action but is strictly passive; age or gender precludes their participation in the war. Another context involving spectators are the funeral games for Patroclus $(23.448-472) .^{11}$

A third context in which we find embedded focalization ( 7 instances) concerns generals who watch their troops either before or during battle, for instance

\footnotetext{
$7 \quad$ I concentrate on instances of embedded focalization which concern visual perception.

8 I here draw on de Jong 2004, 102-110.

9 Cf. Il. 1.56; 4.4; 7.17-18, 444; 8.52; 10.516; 11.82-83; 13.4-6; 14.154-158; 15.6-12; 17.198-199, 441; 19.340; 20.112-113; 22.158-166; 24.331-332, and see Griffin 1980, 179-204.

10 Griffin 1980, 201.

11 For another teichoscopy, see Il. 21.527; 22.25-32 (Trojans watch the duel between Hector and Achilles) and 463-464 (Andromache watches Hector's corpse being dragged around the city by Achilles), and for other passive mortal spectators, see 10.520-525; 11.601; 14.13$15 ; 24.700$.
} 
Agamemnon who sees how the Athenians and Cephallenians are 'standing still and waiting for others to start the battle' and chides their leaders (4.327-336). ${ }^{12}$

Most instances of embedded focalization (24 instances) occur in battle scenes and involve either a warrior who sees an enemy and attacks, for instance Pandarus who sees Diomedes 'sweeping over the plain while chasing the troops in front of him' and shoots an arrow at his Greek opponent (5.95-96), ${ }^{13}$ or a warrior who sees a friend who is endangered or killed and intervenes to support him or recover his body, for instance Eurypylus who on seeing that Ajax is beset by dense volleys of weapons' positions himself next to him (11.575-576). ${ }^{14}$

Although individual heroes are the main focus of epic, the Homeric narrator also regularly (22 instances) includes the collective embedded focalization by armies. One example is the Paeonians who panic 'when they see their best man in the battle's fury beaten down under the hands and mighty sword of the son of Peleus' (21.207-208). ${ }^{15}$

Outside martial contexts, finally, embedded focalization is found in a variety of situations, for instance when a character sees a god (3.396-397), an unexpected person (24.483), the helmet plume of his father (6.470), or looks at a corpse $(18.235-236 ; 19.283)$. Completely sui generis is the celebrated moment when the enemies Priam and Achilles, after speaking with compassion about their losses, take the time to look at each other in mutual admiration (24.629-633).

In all of the six contexts just sketched the narrator may elaborate on the feelings of the focalizing character in an assimilated simile, i.e. a simile in which the narrator renounces his customary panoramic standpoint ('like bees swarming out from a hollow in the rock ...' or 'like waves crashing on a sheer headland ...') and assimilates his perspective to that of a character. How this works can be illustrated by the two snake similes in the Iliad. The first occurs when Paris sees Menelaus appearing in the frontlines and shrinks back 'like a man who sees a snake in a mountain glen and starts back' (3.30-37); in the second Hector sees Achilles approaching but waits for him 'like a snake waits

\footnotetext{
12 Cf. Il. 4.232, 240, 252-255, 274-283; 12.268; 13.491-495.

13 Cf. Il. 3.21-28, 30-33; 4.467-469; 5.166, 572, 590-596; 8.278-279; 11.581-582; 13.56o-561; 16.818$820 ; 21.49-52$.

14 Cf. Il. 11.248-25o, 521; 16.377-378, 419-420; 17.1-2; 20.419-421. A variant involves a warrior looking around: 4.200-202; 12.333-337; 17.84-86, 115-118, 679-683.

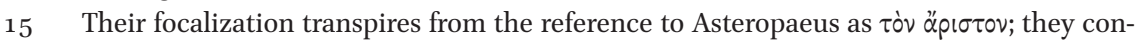
sider him their 'best fighter' while other Greeks will give that qualification to other heroes, notably of course the 'best of the Achaeans' Achilles. Cf. Il. 5.27-29, 514-516; 7.4-7, 206-215, 307-309; 8.75-77, 251-252; 11.459; 12.143-144, 200-209; 13.86-87, 330-331; 14.440; 15.279, 671$673 ; 16.278-279,660-662 ; 17.213-214,724 ; 18.225-227 ; 20.45-46$.
} 
the approach of a man, when he has eaten poisonous herbs and as a result terrible venom has entered him' (22.92-95). In the first case the narrator makes clear how Paris focalizes Menelaus by presenting the simile from the point of view of the man who sees a snake; in the second he illustrates Hector's focalization of Achilles by adopting the reverse position, that of the snake who sees a man. ${ }^{16}$

Speaking broadly, the device of embedded focalization in the Iliad has two functions: it serves to motivate the plot (things happen because characters see something and then react to what they see) and it increases the narratees' interest in and emotional engagement with the story told in that they, for a brief moment, identify with the characters, see what they see and feel what they feel. Embedded focalization in the Iliad, thus, is a prime means to effect enargeia or immersion: when narratees experience the illusion of being present at the events told. ${ }^{17}$

Let us pass now to Quintus and see how he wields the powerful narrative instrument of embedded focalization.

By and large the divine audience in the Posthomerica works the same way as in the Iliad: gods watch in admiration (e.g. Ajax swimming for his life after being shipwrecked by Athena: 14.552-553) or with delight (e.g. the Greeks being routed by Eurymachus and Aeneas: 11.178-179), and sometimes offer support (e.g. Zeus in 10.47-52). ${ }^{18}$ After the virtual disappearance of the divine audience in Apollonius' Argonautica, ${ }^{19}$ Quintus adopts the Homeric model again. Yet at a more detailed level there is also an interesting difference.

This difference consists of the narrator repeatedly indicating that the collective of Olympian spectators consists of two factions, a pro-Trojan and a proGreek one, e.g. when Achilles and Memnon are battling each other:

\footnotetext{
16 See de Jong 2004, 123-136 where a full inventory is given.

17 See e.g. Allan, de Jong, and de Jonge 2017 and Grethlein and Huitink 2017.

18 Cf. Q.S. 7.353-365, 556-562; 8.24-25; 9.182-183; 10.454; 11.168-169; 12.437-439. Brief discussion in Lovatt 2013, 37 n. 29 and 53-54. A special case is Athena averting her gaze when Cassandra is raped (13.425-428); for this phenomenon, which starts with Zeus in Il. 13.1-9, see Lovatt 2013, 71-77.

19 There is only one instance: Q.S. 1.544-552. For the epic tradition of the divine audience, see Lovatt 2013, 29-77 and de Jong 2019.
} 


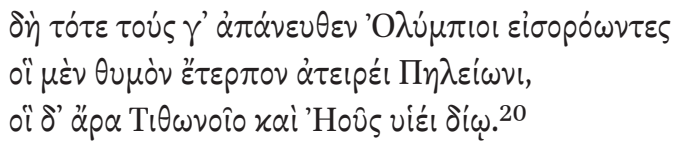

The Olympian gods watching from afar were divided, some favouring the tireless son of Peleus and others the divine son of Tithonus and Eos. ${ }^{21}$

The gods in the Iliad, too, are famously divided into two parties, but this point is never stressed in the context of divine audience scenes. Thus, Homer may report how the pro-Greek goddesses Hera and Athena see that their favourites are in trouble (e.g. Il. 5.418), but he will not indicate at the same time the joy of the pro-Trojan gods. Quintus does give us this parallel arrangement and thereby evokes a picture of the gods, not as just spectators but specifically as supporters of two factions. The famous Blues and Greens of the chariot races in the Graeco-Roman world come to mind here, ${ }^{22}$ and this is the first in a series of signs which, I argue, point at spectacle as an important source of inspiration for Quintus' spectacular style.

Quintus, of course, does not fail to include in his poem the traditional epic Bauformen of teichoscopy (1.403-476 and 9.138-144) and funeral games (Book 4), but again introduces innovations. Thus, the women looking down from the walls at Penthesilea in Book 1 , in a radical departure from the epic tradition, ${ }^{23}$ contemplate coming down and actively participating in the war. They are compared to bees who at the end of the winter are ready to leave their hives and head for their pasture (1.440-449), but, soon after, this role is denied them when one of them, Theano, argues that they have not been trained for martial work and dissuades them from entering the fray. ${ }^{24}$ For a moment Quintus suggests that he is going to break with the tradition of the passive female gaze of teichoscopy, only to adhere to it in the end.

\footnotetext{
20 Q.S. 2.492-494.

21 Cf. Q.S. 3.93-95; 8.194-196; 4.43-47, 93-99; 13.415-419.

22 For the Roman factiones, professional chariot racing associations, which identified themselves and their fans by the colours worn by the charioteers, see e.g. Cameron 1993; Futrell 2006, 210-212; Kyle 2007, 258-259 and 309-310. The same phenomenon of partisanship can be observed in the funeral games (Q.S. 4.197-198, 256-258, 339-340).

23 For the epic (and tragic) tradition of teichoscopy, see Lovatt 2013, 217-250.

24 Lovatt 2013, 247-249.
} 
Turning to the funeral games, what stands out here is the frequency (16 times) with which not only the presence of spectators is acknowledged but also their cheering, which once more conjures up the atmosphere of the arena: e.g. in the foot-race between Teucer and Ajax, the two men speed away from the start, race neck and neck 'and the Greeks lining the course look on and cheer their

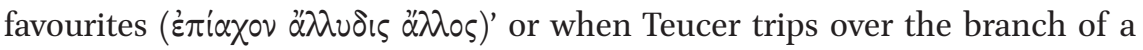
tamarisk bush 'the Greeks at the contest roar' (4.197-198, 205-206). ${ }^{25}$

Quintus also adds to the epic repertoire of non-combatant spectators. In the course of a long and fierce battle-scene he introduces shepherds as focalizers:

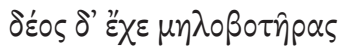

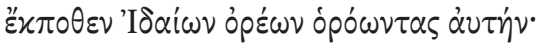

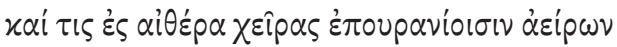

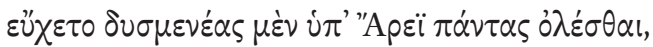

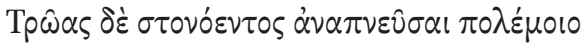

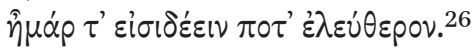

Fear gripped shepherds who were watching the battle from a high point on the Idaean mountains. And many a one raising his arms to the sky prayed the gods in heaven that the enemy be completely destroyed and the Trojans gain some relief from the woeful war and see at last the day of their deliverance.

This passage combines two traditional epic elements: 1) the herdsman as witness in similes (e.g. Il. 4.275-279, where a goatherd in a simile shivers at the sight of a dark cloud and drives his flock into a cave $)^{27}$ and 2) the collective tis-speech (e.g. Il. 3.319-324, when both Greeks and Trojans pray to Zeus that either Paris or Menelaus, who are about to engage in a duel, 'is killed and enters Hades, while we have peace and a reliable truce'). ${ }^{28}$ Quintus' first step consists

25 Cf. Q.S. 4.147-148, 171, 218-219, 231, 256-258, 262, 339-341, 414-417, 443-444, 458-459, 467, 473474, 561-562, 581-584. In the Homeric funeral games, there are virtually no references to spectators or cheering. E.g. in the chariot race, the narrator first focuses on the charioteers (Il. 23.362-447), then briefly switches to the spectators (but only notes what they see and say: 448-498), and then turns to the charioteers again (499-533).

26 Q.S. 11.266-271.

27 Cf. Q.S. 3.11; 4.455; 8.559; and 13.493. For examples from the epic tradition, see e.g. Verg. A. 2.307-308 and Sil. Pun. 7.364-366.

28 For other Iliadic tis-speeches, see de Jong 1987. For examples from the epic tradition cf. e.g. A.R. 1.242-246, 251-259; and 4.1251-1258. 
of lifting the herdsman-spectator out of his usual epic habitat, the simile, and placing him into the main story. ${ }^{29} \mathrm{Next}$, he gives him a collective voice and allows him to express, in indirect speech, his focalization of the war; like the soldiers of the Iliad, he longs for it to end.

\section{Generals, Warriors, and Collectives}

When we turn to the focalization by generals and by warriors in battle, a remarkable fact presents itself: while these two categories take up the bulk of the embedded focalization in the Iliad, they are rare in Quintus. I have found only seven instances: $2.261-262$, 396-397; 6.436, 513-514; 9.224-225; 11.387, and 475-476. This low number may be due to the simple fact that the Posthomerica deals with much more than battles (and the Iliad) alone; it covers, more or less, the same ground as the Aethiopis, Little Iliad, and the Sack of Ilion. ${ }^{30}$

However, what we find more of, and in a higher percentage than in the Iliad, ${ }^{31}$ is embedded focalization by the Greek or Trojan collectives, e.g. in the following passage:

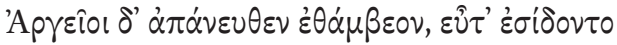

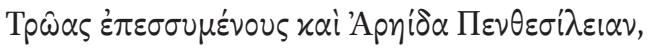

...

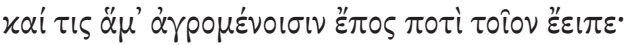

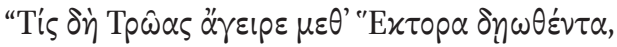

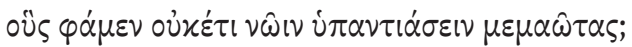

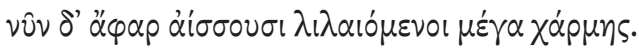

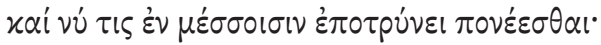

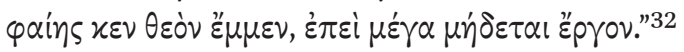

29 This happens again in 5.433-438; 10.367-370, 46o-464, and 479-482.

30 For the vexed question of Quintus' relationship to these poems from the Epic Cycle, see the overview in Bär and Baumbach 2015, 6o6-614, who conclude that they are "unable finally to decide upon the role which an almost entirely lost corpus of texts may have played in the virtually infinite net of possible hypotexts within which Quintus navigates in a creative manner" (614). Hence my 'more or less'.

31 The Posthomerica has a total of 8.772 lines, of which 16 o lines $(2 \%)$ is taken up by collective embedded focalization. The figure for the Iliad is: 71 lines (on a total of 15.693 lines), which means ca. $0.5 \%$.

Q.S. 1.205-216. 
The Argives were struck with amazement when in the distance they saw the Trojans and Penthesilea, daughter of Ares, charging toward them ... As they mustered together, one said to the other: "Who has mustered the Trojans now that Hector is dead? We thought that they were no longer keen to meet us, here they are suddenly rushing out and eager for the fight! There is someone in their midst urging them to the task-you would think it was a god, so great is the exploit he has in mind."

In his commentary, Bär shows how Quintus here combines two Iliadic intertexts: the speech by Thoas who notes the return of Hector to battle after having been severely wounded (15.286-299) and a collective tis-speech like $4.81-85^{33} \mathrm{I}$ would also like to draw attention to Quintus' subtle use of focalization. When he says that the Greeks 'saw Penthesilea', he intrudes upon their focalization, in order to leave no doubt with his narratees who the person focalized is. The Greeks themselves, however, do not recognize Penthesilea but assume the new leader to be a man. The effect is that the martial power of the queen of the Amazons is effectively paid a compliment. ${ }^{34}$ Quintus here again reveals himself as being a keen student of Homeric narrative techniques, since Homer performed the same sleight-of-hand in his teichoscopy: first reporting that Priam 'saw Odysseus', he then makes the Trojan king ask Helen 'who is this man?' (3.191-198).

Time and again we look at the events of the Posthomerica through the eyes of the Greeks and the Trojans, who see warriors arriving in their camp/city (1.53-61, 62-73; 2.102-106; 6.124-131; 9.445-446), departing from it (2.582-585; $6.114-115 ; 12.353-355)$, entering battle $(1.515-521 ; 6.295-296)$, approaching $(2.202-$ 203; 9.75-79; 10.5-7), killing (8.218-219) or being killed (1.630; $3.351-352)$. Also popular is the collective focalization of dead bodies (1.661-670; 3.179-185, 541543; 5.487-490; 10.468-469, 479-482), an intertextual offshoot of the inspection by the Greeks, in a mixture of fright and admiration, of the corpse of Hector (Il. 22.369-375).

This interest in collective focalization clearly distinguishes Quintus from Homer. Once more, I would be inclined to relate this observation to Quintus' indebtedness to the spectacles of his time, and more generally to the theatricality of the late antique world (more on which in my conclusion).

\footnotetext{
33 Bär 2009, 5o6-5o9.

34 Differently Scheijnen 2018, 54: "from a distance, she is only perceived as a strong battle commander" (rather than a god).
} 


\section{Embedded Focalization outside Martial Contexts: The Arrival of Champions}

It would take up too much space here to analyse all instances of embedded focalization outside martial contexts, ${ }^{35}$ but there is one very distinct innovation which I would like to single out for discussion. This concerns the repeated use of embedded focalization (or, as I call it, serial embedded focalization), by both individuals and collectives, at the moment of the arrival of a champion, a hero or heroine who is a new arrival to Troy coming in order to support either Greeks or Trojans.

This technique of serial embedded focalization, for which there is no Homeric parallel, ${ }^{36}$ is employed by Quintus in connection with Penthesilea, Memnon, Eurypylus, Neoptolemus, and Philoctetes. Embedded focalization marks (1) (in the case of Philoctetes and Neoptolemus who have to be fetched from Lemnos and Scyros respectively by an embassy) the first sight of the escortee, (2) the moment when the hero/heroine arrives in the city of Troy or the Greek camp before Troy and is hospitably received, and (3) the moment when s/he appears for the first time on the battlefield. Schematically this leads to the following picture for Penthesilea, Memnon, Eurypylus and Philoctetes (leaving Neoptolemus to be discussed in full below):

\begin{tabular}{lllll}
\hline & Penthesilea & Memnon & Eurypylus & Philoctetes \\
\hline first sight escortee & - & - & - & $9 \cdot 355^{-397}$ \\
arrival in Troy/Greek & $1.53^{-61,70-72,}$ & $2.102-110$ & $6.124-130$, & $9 \cdot 445-446$, \\
camp and reception & $74-85$ & & $130-132,156$, & $459-461,469-472$, \\
& & & $173-175$ & $480-481$ \\
first appearance on & $1.205^{-210}$ & $2.202-203$ & $6.295^{-296}$ & -37 \\
battlefield & & & & \\
\end{tabular}

Serial embedded focalization is used on the largest scale, no less than seven times, by Quintus in connection with Neoptolemus, who is one of the central

E.g. the focalization by travellers (Q.S. 1.294-306; 6.482-483; 7.545; 11.93-98). In general for Quintus' touristic interest, see Kauffman 2018, 638-639.

36 But it can be observed in A.R. 1.544-552, see my analysis in de Jong 2018, 27-28.

37 Rather than recording Philoctetes' first appearance on the battlefield, the narrator remarks after a number of battle scenes: 'no warrior was hardy enough to come near to the valiant son of renowned Poeas if once he caught sight of him, even from far off' (Q.S. 10.176-177). 
figures of the Posthomerica: he dominates Books 7-8, appears on and off in the battle of Books 9-11 and unlike the other champions Penthesilea, Memnon, and Eurypylus survives the war, and thus is able to play a major role in Books 12-14, the sack of Troy and its aftermath. ${ }^{38}$

In light of this central role of Neoptolemus we can understand why his arrival is presented with so much narrative fanfare by Quintus. Let us take a closer look at how this works. The first to set eyes on Neoptolemus are Odysseus and Diomedes, who come to Scyros to collect him (7.170-177). They find him practising with bow and spear and exercising with his horses, are delighted to see him training for war, and are also amazed to observe how closely he resembles his father.

When Neoptolemus leaves home and sets out for the ship that will bring

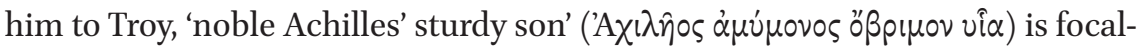
ized with delight by the Nereids and Poseidon (7.353-355), in an intertextual reworking of the Colchians' (worried) focalization of the departing Jason and the Argonauts (A.R. 1.237-26o). Quintus opts for 'marine' focalizers in anticipation of the sea-journey to come (cf. Poseidon's role in 7.374-376) and makes them react with joy rather than worry, to build up a contrast with the sorrow of Neoptolemus' mother Deidamia (7.242-287, 315-343, 384-393).

When the embassy with Neoptolemus arrives in the Greek camp at Troy, there is no time for the customary hospitable reception since the Greeks are hard pressed by the Trojans led by Eurypylus. The hero arms himself and right away moves to the battlefield. The Greeks are relieved at seeing Neoptolemus, like sailors finally getting a long-awaited favourable wind (7.452-463), an intertextual reworking of $I l \cdot 7 \cdot 4-7 \cdot 39$

Neoptolemus joins the fighting, but the narrator does not make the Trojans notice him right away. Rather, he first reports the fierce fighting between Greeks and Trojans and Neoptolemus' violent slaying and only then presents the Trojans' focalization of the hero:

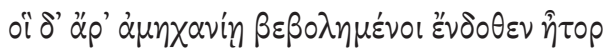

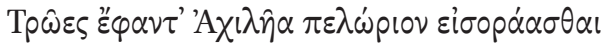

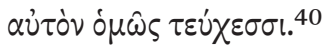

38 I base myself here on the detailed analysis of Neoptolemus by Scheijnen 2018, 156-225 (and passim in later chapters).

39 See Tsomis 2018, 269.

40 Q.S. 7.537-539. 
Shocked and helpless, the Trojans thought it was immense Achilles they were seeing, the man himself and his armour.

Quintus here effectively reworks the Iliadic moment when the Trojans see Patroclus who is wearing Achilles' armour and think that Achilles has returned to battle (16.278-282). Strictly speaking, the Trojans in the Posthomerica know that it cannot be Achilles since he is dead, but their shocked focalization gives a new twist to the leitmotif of Neoptolemus resembling Achilles.

After another round of battle scenes in which Neoptolemus excels, night falls and now, finally, we get the customary 'arrival in the (Greek) camp' element. The first to greet Neoptolemus is old Phoenix, who 'seeing him was astonished to see how like Achilles he was' (7.631).

Then Agamemnon greets Neoptolemus, and voices his focalization in a speech: 'There is no doubt that you are the son of valiant Aeacides, my boy ... The sight of you warms my heart: for I truly have high hopes that by your hands and your spear we will bring ruin to the enemy hordes and to Priam's famous city, because you resemble your father. Indeed I imagine (o $\left.{ }^{i} \omega\right)$ that I am seeing that man ( $\varkappa \varepsilon i v o v$ ) beside the ships at the time when rage at Patroclus' death led him to challenge the Trojans' (7.689-695). Quintus' narrative strategy of changing the order of typical elements, showing us first Neoptolemus in action on the battlefield and only then having him welcomed in the camp, pays off here: Agamemnon's laudatory welcome is no mere politeness but is backed up by what the narratees have read before. For the second time, Quintus makes characters 'see' Achilles when they see his son Neoptolemus; unlike the Trojans, however, who for a brief second really think ( $\varepsilon \varphi \alpha v \tau$ ) they see Achilles, Agamemnon knows that this is only his imagination ( ${ }^{\prime} i \omega$ and note the distal deictic $x \varepsilon i v o v)$.

The last to take a look at the newly arrived champion Neoptolemus is Briseis: 'As for Briseïs, the sight of Achilles' son made her feel now great joy, now sorrow by reminding her of Achilles; and her heart within her was struck with speechlessness, for it was as if truly fearless Achilles was still alive' (7.723-727). Quintus here shows himself a little too enamoured of his own narrative ploy, which he repeats for the third time: like the Trojans and Agamemnon, Briseïs seems to 'see' Achilles when she is actually looking at his son.

In sum, almost all individual instances of embedded focalization which herald the arrival of the new protagonist Neoptolemus have epic predecessors. What constitutes Quintus' originality is their combination into one cumulative series, which-in no uncertain way-hammers home Neoptolemus' resemblance to his father Achilles, and thus functions as a technique of characterization. 
Many instances of embedded focalization discussed in the previous sections have a simile in their vicinity. Quintus' predilection for similes is well known, and this aspect of his poetry has received much scholarly attention. ${ }^{41}$ What interests scholars most is, inevitably, Quintus' use of Homeric or other epic intertexts when composing his own similes. I want to focus on Quintus' adoption of the technique of the assimilated simile, first developed by Homer (see section 1 above).

One of the first similes of the Posthomerica right away provides a clear example:

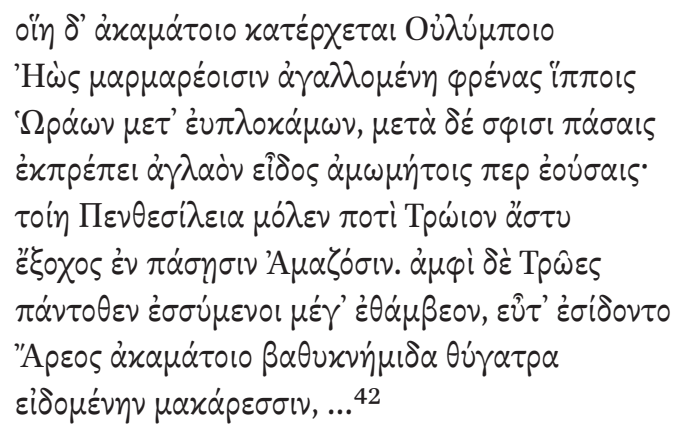

Just as Dawn, glorying in her gleaming steeds, descends from immovable Olympus in the company of the fair-haired Seasons, and among them she stands out resplendent, for all their faultless beauty; just so Penthesilea stood out among the Amazons as she came to the city of Troy. Hastening to gather around her, the Trojans were amazed when they looked upon invincible Ares' deep-grooved daughter, who looked like one of the blessed ones, ...

The comparison of Penthesilea with Dawn suggests how the Trojans focalize her upon her first arrival in their camp: in their eyes she is like a god and her arrival means light after darkness, Dawn after Night. ${ }^{43}$ Penthesilea will receive seven more assimilated similes, which illuminate the stages of her career in

41 For an overview of scholarship on Quintus' similes and quantitative comparison with Homer and Apollonius, see Maciver 2012, 125-128 and Scheijnen 2018, 38-42.

42 Q.S. $1.48-56$.

43 Cf. Maciver 2012, 136: "the shift in narrative perspective to secondary focalizers implies that in the eyes of the Trojans themselves Penthesileia is dawn, heaven-sent help". 
the Posthomerica, from its glorious and hopeful start to its tragic end which is deplored by friend and foe alike $\left(1.62-72,{ }^{44} 74-85,{ }^{45} 205-210,{ }^{46} 353-356,538-546\right.$, 63o-642, 661-668).

Similarly, the focalization of the other newly arriving heroes mentioned in the previous section is strengthened by assimilated similes. Eurypylus provides a particularly fine example:

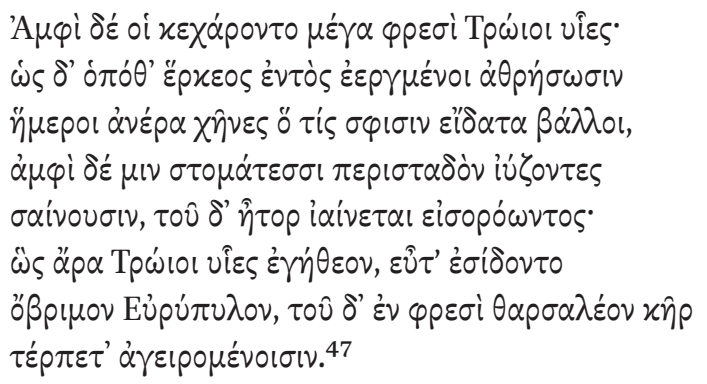

The sons of the Trojans came round him with great joy in their hearts; just as when domestic geese kept in a pen catch sight of the man who throws their food to them, and they gather round to fawn on him with cackling beaks; and his heart is warmed at the sight. Just so the sons of the Trojans were glad when they saw mighty Eurypylus, whose bold heart rejoiced to see them thronging.

One simile, highly efficiently, conveys two perspectives: Quintus first positions himself with the geese/Trojans and records their joy at seeing their master/ Eurypylus, and then halfway switches to the position and focalization of the master who enjoys the sight of his geese gathering around him, and thus prepares for the joy of Eurypylus at seeing the Trojans thronging around him. ${ }^{48}$

44 Cf. Maciver 2012, 137: "the simile illustrates the effect the sight of Penthesileia has on the Trojans".

45 Cf. Maciver 2012,138-139: "the simile depicts Priam's more realistic reaction to Penthesileia's arrival: though largely cured from his blindness the man in the simile still feels pain".

46 Cf. Bär 2009, 5o6: "[es]wird deutlich, dass Quintus darum bemüht ist, Penthesileias Wirken auf die Menschen pluriperspektivisch zu betrachten".

47 Q.S. 6.124-130.

48 Cf. assimilated similes about Memnon: Q.S. 2.102-110, 193-203; Neoptolemus: 7.452-463; and Philoctetes: 10.169-177. Other instances of assimilated similes: 3.179-185, 351-357+358$365 ; 7.452-463 ; 8.412-419$; and 14.57-67 (with Maciver 2012, 148-152). 
The preceding sections have demonstrated the ubiquitous presence of spectators in the Posthomerica. Quintus uses the focalization by characters (like Homer) to motivate the action and increase the narratees' emotional engagement or (an innovation), when applied in a series, as a characterizing technique. In the last part of this chapter I would like to contextualize my findings. My first suggestion would be to add the ample use of embedded focalization to the list of stylistic features which contribute to the well-known visual aesthetics of late antique poetry. ${ }^{49}$ These features include ekphrasis, miniaturization, enumeration, and the juxtaposition of episodic scenes. Quintus, when including the perspectives of many characters rather than focalizing everything himself, creates a kaleidoscopic effect.

The literary penchant for the visual springs from rhetorical education (in which ekphrasis took up a prominent place), the visual arts (mosaics), and even pantomime. The entire Graeco-Roman world in general was highly spectacular and theatrical: triumphs, processions, funerals, public declamations, races, and gladiatorial shows were not only the order of the day in Rome, but also in the Greek East. ${ }^{50}$ All of this will have had its effect on Quintus, but my survey of spectators in the Posthomerica has suggested to me one very pervasive influence: I would like to argue that Quintus frames the action of his story as a spectacle (a race or gladiatorial show), which gods and characters, and hence his narratees, watch as if sitting in an amphitheatre or circus.

My first argument consists of the fact that the Posthomerica actually has a number of references to spectacles. The best known of these references is the simile which unmistakably refers to the execution of criminals by exposing them to wild animals in the arena (damnatio ad bestias): 51

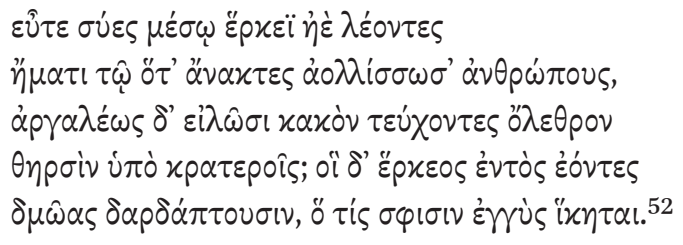

49 The bibliography is rapidly expanding and I only mention some key publications: Roberts 1989; Agosti 2006, 2014; Cadau 2015, 135-221.

$50 \quad$ See e.g. Anderson 1989, 89-103 and Whitmarsh 2001, 247-294, with more literature. Ulrich Eigler suggested to me that we might even consider the possibility that Quintus was consciously adapting his epic tale to a Roman readership.

$5^{1} \quad$ See Kyle 2007, 327-329 and Lovatt 2013, 284-285.

52 Q.S. 6.532-536. 
(The Atrides are surrounded by enemies) like boars or lions penned in on that day when rulers round up human beings in a confined space in the middle and devise for them a horrible death from powerful wild beasts which in that confined space rip and mangle any of those slaves who come near to them. ${ }^{53}$

Next, there are Quintus' inclusion of the long jump and horse race in Achilles' funeral games of Book 4, which do not appear in Homer (who only has chariot racing) but which, as Hopkinson notes, "featured in the games of the Roman imperial period". ${ }^{54}$ The jockeys lead their horses 'to the race course' ('̇ $\left.\delta \rho o ́ \mu o v\right)$, take their whips, jump onto their horses and wait; the horses, eager to start, 'foam at their bit and paw the ground' (4.545-550). Another reference to the horse race, not yet spotted by commentators, is found in a simile: Neoptolemus' eagerness to depart for battle and his mother's attempt to restrain him are compared to a rider who checks his horse, which, eager 'for the race ( $\dot{\varepsilon} \pi i$ Spópov), whinnies and champs at its restraining bit, its chest soaked with foam, its feet never still in their eagerness to be going' (7-317-326). The impatience of horses at the start of a race conjures up the picture of the carceres used in amphitheatres, behind which horses would have to wait until these barriers

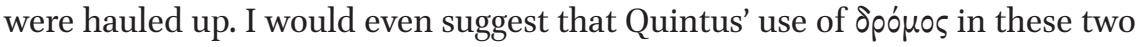
contexts evokes the hippodrome. ${ }^{55}$ The Roman epic poet Statius describes the very same tense moment behind the barriers in his Thebaid (in the context of a chariot race during funeral games):

\author{
iugales \\ ... stant uno margine clausi \\ qui dominis, idem ardor equis; face lumine surgunt, \\ ora sonant morsu, spumisque et sanguine ferrum \\ uritur, impulsi nequeunt obsistere postes
}

53 This is one of two explicit references by Quintus to his own time (the other being 13.366341). Other topical elements are: stoic philosophy, medical details, and techniques of warfare (e.g. 11.358-366: the strategy of the testudo, or interlocking shields held above soldiers' heads; $11.45^{\circ-456}$ : the use of scaling ladders). For an overview of scholarship on topical elements, see e.g. Scheijnen 2018, 2, to which should be added Hadjitoffi 2007.

54 Hopkinson 2018, 193.

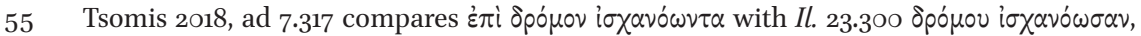
where $\delta$ pópos clearly means 'the act of running' rather than 'the place of running'. This may well have been Quintus' intertext, but this does not preclude an association with the hippodrome, all the more so since we find a spatial preposition+accusative, rather than a genitive. 
claustraque, compressae transfumat anhelitus irae. stare adeo miserum est, pereunt vestigia mille ante fugam, absentemque ferit gravis ungula campum. ${ }^{56}$

... the horses ... stand behind one barrier ... The horses are as ardent as their masters. Their eyes swell fiery, their mouths loudly champ, foam and blood corrode their bits, the posts and bars cannot withstand their push, the pant of stifled rage smokes through. To stand still is torture; a thousand paces are wasted before the start, the heavy hoof strikes the absent flat.

Another potential reference to spectacle is found in 1.543, where we hear, in the context of a simile, about hunters who await the attack of a leopard 'in their

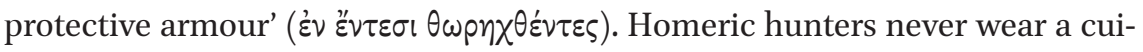
rass, while gladiators in the arena did. In 2.249-250, in another simile, mention is made of a boar 'which is able to face in combat (oî $\delta \varepsilon \mu \alpha \chi \chi \varepsilon \sigma \theta \alpha l$ ) both men and beasts. ${ }^{77}$ Both passages conjure up the image of the spectacles of the 'hunt' or venatio (man against animal) or the beast-contest (animal against animal). ${ }^{58}$

Quintus has quite a number of hunting similes (16 out of $192,{ }^{59}$ as against 8 out of 192 in the Iliad), ${ }^{60}$ and part of the animals hunted are the same as those of venationes: wild goats, lions, boars, leopards, and bears. The first four animals are also found in Homer, but the brown bear is absent from his epics while very much present in the arena. Once reminded of the gladiatorial venatio, we may start looking at Quintus' hunting similes with different eyes: these may evoke not so much real hunts in wild nature (as Homer's similes do) but their artificial and cruel counterpart in the arena. ${ }^{61}$

My second and third argument in favour of spectacles as an inspiration for Quintus' narration have already been mentioned in previous sections: his repeated portrayal of the gods watching in two factions arguably recalls the Green and Blue factions of the chariot races; and his increased use of collective focalization suggests the crowds of an arena.

$5^{6}$ Stat. Theb. 6.391-401. Statius, recounting games from the heroic age, of course refrains from using the word carceres and instead speaks of margine, postes, and claustra. We do find carceres in Hor. S. 1.1.114 and Verg. G. 1.512; 3.104.

57 Hopkinson's translation is even more suggestive: 'which is practiced in fighting men and beast'.

$5^{8}$ For venationes and beast-contests, see e.g. Kyle 2007, 323-327.

59 Scheijnen $2018,39$.

6 o Il. 3.25-28; 8.338-340; 11.292-295, 474-484; 12.41-50; 15.271-278; 18.318-323; and 21.573-580.

61 In Vergil, Lucan, and Statius heroes are also compared to gladiators, see Lovatt 2013, 283293. See also Feldherr 1998 and Oakley 2010 on spectacle in Livy's depiction of early Rome. I thank Ruth Morello for the last two references. 
My fourth argument concerns the emotion most frequently triggered by the characters' perceptions: they overwhelmingly ( 27 instances) react with admiration and amazement $(\theta \alpha \dot{\alpha} \mu \beta-, \theta \alpha \hat{v} \mu-, \tau \varepsilon \theta \eta \pi-),{ }^{62}$ while joy (14), fear (8), and sorrow (4) are far less prominent. This constitutes a marked difference with the Iliad where $\theta \dot{\alpha} \mu \beta$ ○ is much less frequent ( 7 instances) $)^{63}$ than the other emotions. To be sure, admiration is a natural reaction to the sight of an arresting figure like Penthesilea (1.54, quoted above), but its abundant presence in all kind of contexts, including the sight of enemies (2.202-203; 9.75-76), dead animals (5.456-457), dead warriors (10.468-469), or a man groaning in pain (9.355357 ) is remarkable. When we assume Quintus to be presenting his story as a kind of gladiatorial spectacle, however, his use of this emotion is very understandable. ${ }^{64}$ Admiration perfectly suits the idea of spectators who have come to cheer their favourite charioteer, horse or gladiator. It is known, e.g., from graffiti and inscriptions, that all of these could attain the status of stars. ${ }^{65}$

For my last argument I would like to draw attention to a detail easily overlooked and hence not yet picked up by commentators: Quintus often says that a character sees something 'from a distance' ( $\dot{\alpha} \pi \dot{\alpha} v \varepsilon v \theta \varepsilon(\nu), \dot{\alpha} \pi \dot{\delta} \pi \rho \circ \theta \varepsilon(\nu))$, for

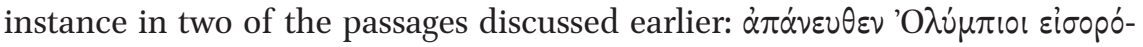

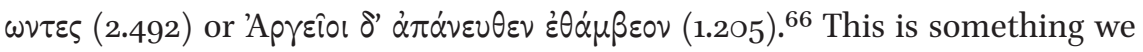
do not find in the Iliad. The fact that Quintus regularly stresses the distance between focalizing character and focalized, between spectator and heroic action, once more, I would like to claim, suggests the position of a spectator in an amphitheatre, where someone sitting in the middle or highest tiers would, indeed, look at the gladiators from a considerable distance.

Continuing this line of thought, I was struck by the frequency of the preposition $\alpha \mu \varphi i$ in the context of embedded focalization, for instance in the passage

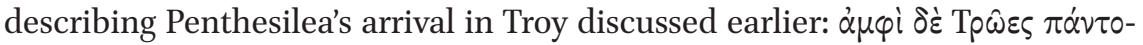
$\theta \varepsilon v \varepsilon^{\prime} \sigma \sigma \dot{v}^{\prime} \mu \varepsilon v o l \mu \varepsilon^{\prime} \gamma^{\prime} \dot{\varepsilon} \theta \dot{\alpha} \mu \beta \varepsilon \circ \nu(1.54-55) .{ }^{67}$ Is it too far-fetched to associate this with the amphitheatre?

Taking all of these six arguments together I fully subscribe to Lovatt's remark, made in connection with Quintus' 'gladiator' simile: "to a Greek living

62 See Q.S. 1.54, 205, 259, 404, 662; 2.202, 583; 3.541; 4.218, 481; 5.457; 6.131, 156, 173, 236; 7.176, 631; 9.76, 236, 355, 480; 10.469; 12.149, 359; 13.393, 398; 14.18, 58, 35०, 6о5.

63 Il. 3.342, 396-398; 4.79; 8.76-77; 23.728, 9.881; 14.483-484.

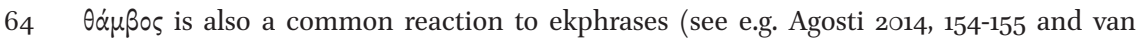
Opstall 2013, 20-22), and this undoubtedly explains its frequency too.

65 See Futrell 2006, 135-138 and 198-203.

66 And see Q.S. 1.259, 403, 476; 2.202; 6.173; 9.267; 12.477; 13.478. Only Ferreccio 2014, ad 2.492 comments: "i dei Olimpici sono lontani, semplici spettatori che non intervengono direttamente nelle vicende umane".

$67 \quad$ And cf. Q.S. 2.102, 582; 4.316; 6.235; 10.479; 12.358, 477, 13.465; 14.57, 349. 
in the Roman empire, then, epic spectacle cannot be hermetically sealed off from Roman spectacle. The brutality of epic battle is always potentially analogous to the glory of the arena". ${ }^{8}$ Here it may be also relevant to recall that Roman spectacle could take the form of mythological enactment, e.g. of the story of Pasiphae and the bull. ${ }^{69}$ This makes the mental leap which both Quintus-narrator and his narratees have to make in order to view the heroic past of the Posthomerica as a kind of present day spectacle all the more easy.

I also see my suggestion corroborated in a recent article by Nicholas Kauffman in which he analyses the battle scenes of the Posthomerica and observes that Quintus 1) presents slaughter not in pathetic terms (as happens in the Iliad) but as something to be looked at with amazement, for instance when we hear about a hand severed from a warrior's body 'which still firmly grips the curved bit, just as it did while he was still alive, and it was a great wonder (thauma)' (11.194-195), 2) includes more, and more massive collective killings than Homer, and 3) often indicates via similes the pleasure of killing, for instance in 9.162-168. ${ }^{70} \mathrm{He}$ concludes that Quintus "inhabited a milieu in which the slaughter of human beings could be construed as entertainment, and the aesthetics of violence in his own poem seems to reflect this milieu. In describing slaughter in his epic, we might say, he has created something like an equivalent to the arena shows in literary form, using the death of individuals and masses to surprise and delight his audience, showing them wonders far different from those they might find in the epics of old" (my italics). ${ }^{71}$

I would like to conclude that not just one gladiatorial simile, not just the battle scenes, but the entire action of the Posthomerica is presented as a spectacle, and Quintus' narratees are invited to take up seats in an imaginary arena and look at the exertions of the heroes from a distance. The difference with Homer, who for the larger part of the Iliad positions himself shoulder to shoulder with his battling heroes, ${ }^{72}$ could not be greater! This study, thus, shows that the investigation of an author's originality should include other factors than language alone: underneath the strong Homeric patina with

\footnotetext{
68 Lovatt 2013, 285 .

69 See e.g. Mart. Sp. 6, 7, 9 and Coleman 1990.

70 Kauffman gives as other examples: Q.S. $3.377-378 ; 7.575 ; 8.334$.

71 Kaufmann 2018, 648. For a brief diachronical discussion of the depiction of slaughter in ancient epic, see Dinter 2019. Dinter notes that Vergil features many gruesome deaths, and Lucan even more; that Statius, Valerius Flaccus, and Silius Italicus cut back on excessive violence; and that Quintus is more violent again (but he discusses only two instances). 
which Quintus overlaid his story many unhomeric, that is contemporary, things are going on. ${ }^{73,74}$

\section{Bibliography}

Agosti, G. (2006). Immagini e poesia nella tarda antichità. Per uno studio dell'estetica visuale della poesis greca fra iii e vi sec. d. C. In: L. Cristante, ed., Incontri Triestini di Filologia Classica IV, Trieste, pp. 351-374.

Agosti, G. (2014). Contextualizing Nonnus' Visual World. In: K. Spanoudakis, ed., Nonnus of Panopolis in Context. Poetry and Culture in Late Antiquity, with a Section on Nonnus in the Modern World, Berlin, pp. 141-176.

Allan, R.J., de Jong, I.J.F., and de Jonge, C.C. (2017). From Enargeia to Immersion. The Ancient Roots of a Modern Concept. Style 51, pp. 34-51.

Anderson, G. (1989). The Pepaideumenos in Action. Sophists and their Outlook in the Early Empire, $A N R W$ II 33.1, pp. 79-208.

Bär, S. (2009). Quintus Smyrnaeus, 'Posthomerica' 1. Die Wiedergeburt des Epos aus dem Geiste der Amazonomachie. Mit einem Kommentar zu den Versen 1-219. Göttingen.

Bär, S., and Baumbach, M. (2015). The Epic Cycle and Imperial Greek Epic. In: M. Fantuzzi and C. Tsagalis, eds., The GreekEpic Cycle and its Reception. A Companion, Cambridge, pp. 604-622.

Baumbach, M., and Bär, S., eds. (2007). Quintus Smyrnaeus. Transforming Homer in Second Sophistic Epic. Berlin/New York.

Cadau, C. (2015). Studies in Colluthus' Abduction of Helen. Leiden.

Cameron, A. (1993). Circus Factions. Blues and Greens at Rome and Byzantium. Oxford.

Coleman, K.M. (1990). Fatal Charades. Roman Executions Staged as Mythological Enactments.JRS 83, pp. 44-73.

Dinter, M. (2019). Death, Wounds, and Violence in Ancient Epic. In: C. Reitz and S. Finkmann, eds., Structures of Epic Poetry, Vol. 2.1: Configuration, Berlin/Boston, pp. 447-481.

Feldherr, A. (1998). Spectacle and Society in Livy's History, Berkeley.

Ferreccio, A. (2014). Commento al Libro II dei Posthomerica di Quinto Smirneo. Rome. Futrell, A. (2006). The Roman Games. A Sourcebook. Malden, MA/Oxford/Victoria.

73 This means that the following remarks by James need to be qualified: "If we examine Quintus' work for indications of its period, we find that there are hardly any, such was the success with which he reproduced the archaic character of the Homeric epics and avoided anachronisms" (2004, xviii, my italics); "It is true that Quintus' epic, unlike, for example Apollonius Rhodius' Argonautica or Nonnus Dionysiaca, does not seek to differ in style from the Homeric epics" (2007, 157, my italics).

74 I wish to thank audiences in Manchester and Zürich for their comments, and Nina King for correcting my English. 
Grethlein, J., and Huitink, L. (2017). Homer's Vividness. An Enactive Approach. JHS 137, pp. 1-25.

Griffin, J. (1980). Homer on Life and Death. Oxford.

Hadjitoff, F. (2007). Res Romanae. Cultural Politics in Quintus Smyrnaeus' Posthomerica and Nonnus' Dionysiaca. In: M. Baumbach and S. Bär, eds., pp. 357-378.

Hopkinson, N. (2018). Quintus Smyrnaeus, Posthomerica. Cambridge, MA/London. James, A. (2004). Quintus of Smyrna. The Trojan Epic Posthomerica. Baltimore/London. James, A. (2007). Quintus of Smyrna and Virgil. A Matter of Prejudice. In: M. Baumbach and S. Bär, eds., pp. 145-157.

de Jong, I.J.F. (2004). Narrators and Focalizers. The Presentation of the Story in the Iliad. London [1st ed. Amsterdam 1987].

de Jong, I.J.F. (2018). The View from the Mountain (oroskopia) in Greek and Latin Literature. CCJ 64, pp. 23-48.

de Jong, I.J.F. (2019). From oroskopia to ouranoskopia in Greek and Latin Epic. In: SO 93, pp. 1-25 [= S. Bär and A. Maravela, eds., Narratology and Intertextuality. New Perspectives on Greek Epic from Homer to Nonnus].

de Jong, I.J.F., and Nünlist, R. (2004). From Bird's Eye View to Close Up. The Standpoint of the Narrator in the Homeric Epics. In: A. Bierl, A. Schmidt, and A. Willi, eds., Antike Literatur in neuer Deutung, Leipzig, pp. 63-83.

Kauffman, N. (2018). Slaughter and Spectacle in Quintus Smyrnaeus Posthomerica. $C Q$ 68, pp. 634-648.

Kyle, D.G. (2007). Sport and Spectacle in the Ancient World. Malden, MA/Oxford/ Victoria.

Lovatt, H. (2013). The Epic Gaze. Vision, Gender and Narrative in Ancient Epic. Cambridge. Maciver, C.A. (2012). Quintus Smyrnaeus' Posthomerica. Engaging Homer in Late Antiquity. Leiden/Boston.

Oakley, S.P. (2010). Dionysius of Halicarnassus and Livy on the Horatii and the Curiatii. In: C.S. Kraus, J. Marincola, and C. Pelling, eds., Ancient Historiography and its Contexts. Studies in Honour of A.J. Woodman, Oxford, pp. 118-138.

van Opstall, E.M. (2013). Cave and Cosmos. Sacred Caves in Greek Epic Poetry from Homer (eighth century в СE) to Nonnus (fifth century CE). In: J.J.H. Klooster and J. Heirman, eds., The Ideologies of Lived Space in Literary Texts, Ancient and Modern, Gent, pp. 15-33.

Roberts, M. (1989). The Jeweled Style. Poetry and Poetics in Late Antiquity. Ithaca, NY/ London.

Scheijnen, T. (2018). Quintus of Smyrna's Posthomerica. A Study of Heroic Characterization and Heroism. Leiden/Boston.

Tsomis, G.P. (2018). Quintus Smyrnaeus. Kommentar zum siebten Buch der Posthomerica. Stuttgart.

Whitmarsh, T. (2001). Greek Literature and the Roman Empire. The Politics of Imitation. Cambridge. 